\title{
Energy, Carbon Dioxide and Water Use Implications of Hydrous Ethanol Production
}

\author{
Howard A. Saffy, ${ }^{a}$, William Northrop ${ }^{b}$, David Kittelson $^{b}$, Adam M. Boies $^{a, c, *}$ \\ ${ }^{\mathrm{a}}$ Department of Engineering, University of Cambridge, Trumpington Street, Cambridge CB2 \\ 1PZ, United Kingdom. \\ ${ }^{\mathrm{b}}$ Department of Mechanical Engineering, University of Minnesota 111 Church St. SE \\ Minneapolis, MN, USA 55455 \\ ${ }^{\mathrm{c}}$ Department of Civil, Environmental and Geo- Engineering, University of Minnesota 500 \\ Pillsbury Drive, Minneapolis, MN, USA 55455 \\ *Corresponding author: a.boies@eng.cam.ac.uk
}

\begin{abstract}
:
Sub-azeotropic hydrous ethanol has been demonstrated as an effective diesel fuel replacement when used in dual-fuel compression ignition engines. Previous studies have also suggested that hydrous ethanol may be more efficient to produce from corn than anhydrous ethanol. In this study, we investigate corn ethanol production from a dry-mill, natural gas-fired corn ethanol refinery, producing ethanol with a range of ethanol concentrations from 58 wt\% $100 \mathrm{wt} \%$ to determine the effect on energy use, water consumption and greenhouse gas (GHG) emissions in the refining stage of the corn ethanol lifecycle. A second law (exergy) analysis of anhydrous ethanol refining revealed the overall process to be $70 \%$ efficient, whereby $86 \%$ of the exergy losses could be accounted for by three processes: fermentation (34\%), steam generation (29\%) and distiller's grains and solubles drying (23\%).
\end{abstract}

We found that producing $86 \mathrm{wt} \%$ ethanol is optimal as thermal energy consumption decreases by a maximum of $10 \%$ (from $7.7 \mathrm{MJ} / \mathrm{L}$ to $6.9 \mathrm{MJ} / \mathrm{L}$ ). These savings have the potential to reduce energy costs by approximately $8 \%(\$ 0.34 / \mathrm{L})$ and reduce refinery emissions by $8 \%$ $\left(2 \mathrm{~g} \mathrm{CO}_{2} \mathrm{e} / \mathrm{MJ}\right)$. Production of hydrous ethanol reduced refinery water use due to decreased evaporative losses in the cooling towers, leading to water savings of between 3 - $6 \%$ at $86 \mathrm{wt} \%$ ethanol.

\section{INTRODUCTION}

A confluence of environmental, economic and energy security concerns have led to laws encouraging the development of a significant biofuels industry in the U.S. Legislation requires that 15 billion gallons of conventional biofuels be produced annually until at least 2022 [1], which accounts for approximately $10 \%$ of all fuel sold in the U.S. Approximately $99 \%$ of this 
conventional biofuel is anhydrous corn ethanol [2] (containing a maximum of $1 \%(\mathrm{v} / \mathrm{v})$ water [3]), mostly derived from corn in the mid-west region.

Corn ethanol has received criticism for its net energy ratio (NER - final fuel energy content/input energy) and net $\mathrm{CO}_{2}$ emissions. The industry has made significant improvements in energy efficiency over the years; however, the net energy ratio of corn ethanol remains fairly low with values between 1.3 and 1.7 being reported in the literature [4-9]. Previous work has shown that while ethanol refiners with similar operation (dry-mill, natural gas fired) have similar refining fuel carbon intensities ( $\left.\sim 64 \mathrm{~g} \mathrm{CO}_{2} \mathrm{e} / \mathrm{MJ}\right)$, the fuel carbon intensity (FCI) can vary up to $10 \%$ for individual refineries and that there is an overall trend to reduce FCI by $\sim 0.5 \mathrm{~g} \mathrm{CO}_{2} \mathrm{e} / \mathrm{MJ}$ per year [10].

Approximately $40 \%$ of the energy consumed in the refinery is used to dehydrate ethanol from the fermentation concentration of approximately $14 \mathrm{wt} \%$ ethanol to pure ethanol, i.e. in the process of distilling and dehydrating [11]. A study by Ladisch and Dyck [12] found that the energy required to remove water by distillation increases exponentially from $~ 92 \mathrm{wt} \%$ ethanol to the ethanol-water azeotrope at $95.6 \mathrm{wt} \%$ ethanol (at $78.2^{\circ} \mathrm{C}$ and $1.013 \mathrm{bar}$ ) [13]. This led others to infer that significant energy reductions could be achieved by producing hydrous ethanol with a concentration of less than $92 \mathrm{wt} \%$ ethanol [14]. However, refineries have already circumvented this problem by ending distillation at $\sim 91 \mathrm{wt} \%$ ethanol and then removing the remaining water via molecular sieves consisting of zeolite (crystalline metal aluminosilicate) beads with pore sizes from 3 - $5 \AA$, achieving purities in excess of 99 wt\% ethanol [15-16]. Since this advance, there has been no further peer-reviewed study on the refinery energy savings associated with hydrous ethanol production.

Study of hydrous ethanol production is motivated by recent research demonstrating the viability of using hydrous ethanol in diesel engines $[14,17,18]$ with results that indicate hydrous ethanol may improve engine efficiency and lower emissions due to the cooling effect of the water during combustion. When used to enable low temperature combustion modes in diesel engines, dual-fuel strategies using separately injected hydrous ethanol and diesel have the potential to meet legislative standards for nitrogen oxide $\left(\mathrm{NO}_{\mathrm{x}}\right)$ and particulate matter (PM) emissions without expensive catalytic after treatment [19].

In light of these end-use benefits, this study examines the implications (energy, $\mathrm{CO}_{2}$ emissions and water use) of producing hydrous ethanol within current dry-mill natural gas-fired refineries. We examine refining from a conservation of energy (first law of thermodynamics) and exergy (second law of thermodynamics) perspective to develop insight into the nature of energy and exergy losses for a range of hydrous ethanol water concentrations. The implications of leaving water in the final ethanol fuel are also examined in terms of overall refinery water usage. Finally, the savings from hydrous ethanol production are compared to other refining options, including: utilizing a combined heat and power (CHP) plant; using biomass-fired boilers, and producing wet distillers grains rather than dried distillers grains.

\section{METHODS}

\subsection{Dry-Mill Corn Ethanol Refinery}

A base case 100 Million Gallon per Year (MGY) dry-mill, natural gas-fired, corn-ethanol refinery was modelled in Aspen Plus ${ }^{\circledR}$ Version 8.4 (® 2013 Aspen Technologies, Inc., Cambridge, MA), a commercial chemical engineering simulation software package, using a modified version of an anhydrous refinery developed by the United States Department of Agriculture's Agricultural Research Service (USDA-ARS) [20]. The input parameters of the model were verified through literature searches and data obtained from visits to three Midwest 
ethanol refineries. The full list of parameters used in the model can be found in the supplementary information (S.I.).

A typical process flow diagram for a corn ethanol refinery is shown in Figure 1 [11, 21-25]. Corn, consisting of 75\% starch (dry mass basis) and 15\% moisture (as verified through refinery visits), is input into the refinery and sent through a hammer mill. The resulting flour is mixed with recycled process water and sterilized before undergoing saccharification and fermentation to convert the starch to ethanol and $\mathrm{CO}_{2}$. The $\mathrm{CO}_{2}$ is removed and the ethanol mixture (containing $14 \mathrm{wt} \%$ ethanol) is sent to distillation to bring the mixture to $91 \mathrm{wt} \%$ ethanol. Due to the presence of the ethanol/water azeotrope, the remaining water is separated out using a molecular sieve. The pure ethanol stream (100 wt\%, 200 proof ethanol) is then mixed with denaturant (up to $\sim 4.7 \mathrm{wt} \%$ gasoline), before it leaves the refinery as final product [22].

The undissolved solids are separated out with the remaining water at the bottom of the column. This slurry, known as stillage, is sent to a centrifuge for the start of the drying process. The overflow is sent to a three-effect vacuum evaporation section which uses the heat of condensation from distillation to drive off a portion of the remaining water and return it to the process. The resulting syrup is combined with the centrifuge underflow and sent to the drum dryer to dry the distillers' grains and solids (DDGS) to $9 \mathrm{wt} \%$ moisture to prevent it from rotting [23].

Natural gas was used as the fuel source for steam production and drying of distiller's grains. A Non-Random Two Liquid (NRTL) thermodynamic model [26] was used for the liquid phase while the ideal gas equation of state was used for the vapour phase [27]. Although some of the unit operations occur as batch processes in a physical refinery, we model the refinery as a continuous process which has no effect on the total mass and energy balances for steady-state operation.

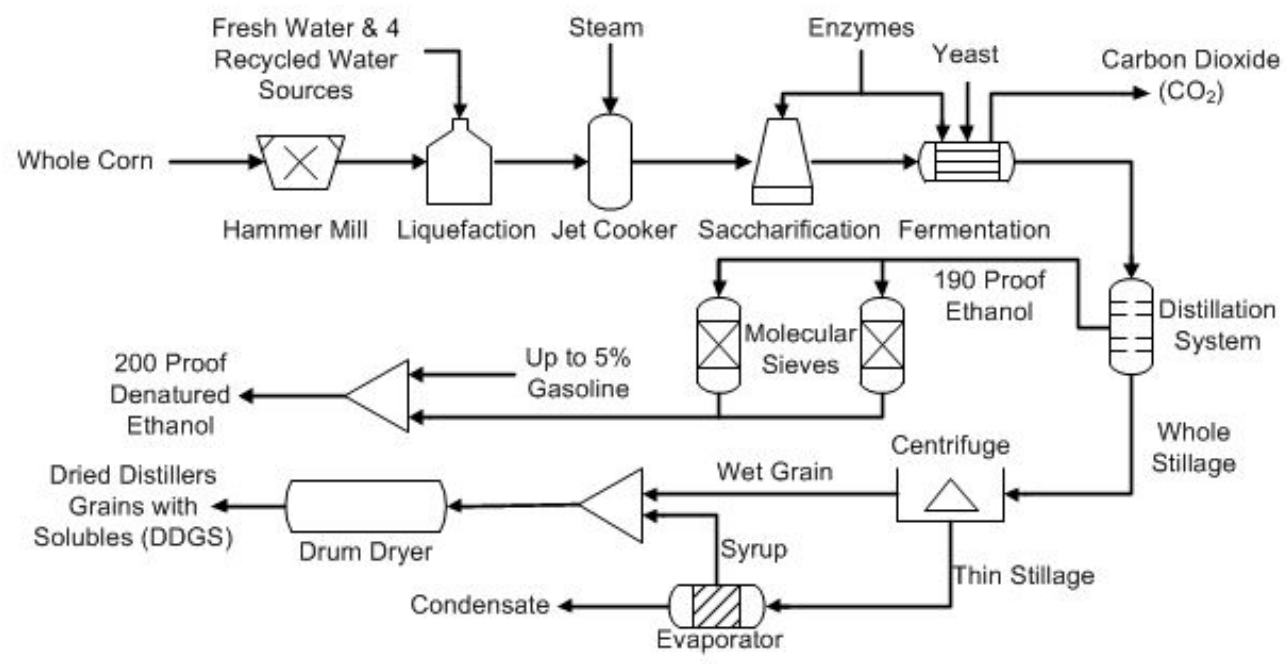

Figure 1. Schematic of modelled corn ethanol dry mill process for pure (anhydrous) ethanol production. 


\subsection{Hydrous Ethanol Process Description}

The modelled anhydrous refinery produces ethanol with a purity of greater than $99 \mathrm{wt} \%$. To produce hydrous ethanol with ethanol concentrations down to $58 \mathrm{wt} \%$, the model depicted in Figure 2 was manipulated to achieve discrete, optimized hydrous levels. For $91 \mathrm{wt} \%$ ethanol, the molecular sieve and the associated recycle stream was removed with no change to the beer or stripping and rectification columns. To produce ethanol between $58 \mathrm{wt} \%$ and $91 \mathrm{wt} \%$ ethanol, the required distillate purity in the rectifying column was adjusted by changing the number of stages and the reflux ratio within the column, and the feed location of the distillate from the beer column was optimized for minimum energy consumption. Heat of condensation of the fluid leaving the stripping and rectification column is recycled back into the process within the 3effect vacuum evaporators, that evaporate water from the wet distiller's grains with solubles (WDGS) to the limit at which viscosity of the slurry begins to inhibit flow within the pipes (typically 35\%). The fraction of ethanol in the water and solids stream from the beer column was held below $0.05 \mathrm{wt} \%$, as is typical of refinery operation that is seeking to maximize ethanol production. In all cases, the total combined stages of the stripping and rectification column remained constant at 18 .

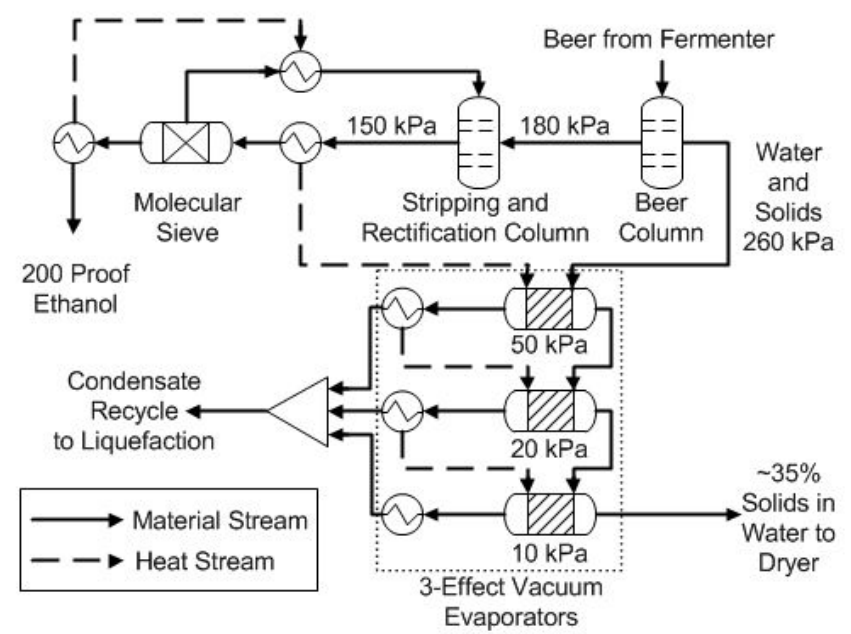

Figure 2. Section of the anhydrous model showing pressure distillation followed by vacuum evaporation with a 3-effect evaporator.

\subsection{Energy, $\mathrm{CO}_{2}$ and Water Parameters}

Thermal energy use (MJ of natural gas used based on the lower heating value, LHV) is defined as the energy required to produce steam for the beer column reboiler, the stripping column reboiler, liquefaction section and molecular sieve pre-heating, and the energy required in the DDGS natural gas fired dryer. This has taken into account an assumed best case thermal efficiency for a boiler of 0.9 [28] and 0.7 for a dryer [29, p. 12.56].

A natural gas price of $\$ 4.22 / G J$ and an electricity price of 7.06 US cents/kWh is used throughout the report, based on average values for Minnesota for 2013 [30-31]. Electricity use was not modelled directly, and an average value of $0.21 \mathrm{kWh} / \mathrm{L}$ of the refiners visited was used, which is consistent with past findings [10]. An average U.S. carbon intensity of $503 \mathrm{~g} \mathrm{CO}_{2} \mathrm{e} / \mathrm{kWh}$ was used to calculate greenhouse gas emissions from grid-electricity consumption [32].

Total water use is a combination of boiler blowdown losses (assumed at $2 \%$ of steam use), clean-in-place (CIP) water use $\left(0.12 \mathrm{~L}_{\text {water }} / \mathrm{L}_{\text {ethanol }}\right)$ [20], evaporative losses and process water 
use. Evaporative losses on the plant were calculated using the method described in Perry et al [29, p. 12.17] and an upper value of 5 for cycles of concentration (typical values are between 3 and 5 [29]), with cooling water mass flow calculated using an energy balance with a temperature difference of $6.7^{\circ} \mathrm{C}$ based on refinery operating data and a constant heat capacity for water of $4.18 \mathrm{~kJ} /(\mathrm{kg} \cdot \mathrm{K})$. Process water use accounts for the water that leaves in the product streams, i.e. with the DDGS and ethanol, and is calculated within the model.

The pinch analysis represents the optimal use of heat within the refinery recycled between unit operations (process integration) where a finite temperature difference exists to drive heat transfer. The pinch analysis was conducted according to the method of Linhoff and Hindmarsh [33] using a minimum approach temperature of $10^{\circ} \mathrm{C}$.

\subsection{Exergy Analysis}

An exergy analysis was conducted over the refinery according to the method of Szargut, Morris and Steward [34], assuming steady state, adiabatic operation and an environment at $298 \mathrm{~K}$ and $101.3 \mathrm{kPa}$. Enthalpy, entropy and exergy values are calculated relative to this state for the streams within the model. Chemical exergy values for the pure components are taken from Szargut, Morris and Steward [34], and are (in kJ/kgmol): 3970 for $\mathrm{O}_{2} ; 19,870$ for $\mathrm{CO}_{2}$ (g); 9500 for $\mathrm{H}_{2} \mathrm{O}$ (g); 900 for $\mathrm{H}_{2} \mathrm{O}$ (l); 1,357,700 for ethanol (l); 831,650 for methane (g); and 2,928,800 for glucose. The exergy value for sucrose was calculated according to the method explained in Moran and Shapiro [35, p. 663]. Exergy losses for electricity generation were ignored as this was beyond the boundary of our analysis and has already been examined (e.g. [34]).

\subsection{Combined Heat and Power Plant}

\subsubsection{Natural Gas-Fired CHP Plant}

A CHP plant was modelled to quantify the savings associated with generating electricity through a gas turbine (GT) on site and using a heat recovery steam generator (HRSG) to recover turbine exhaust gases for process heating. The operation of a combined GT and HRSG were modelled in thermodynamic software developed over several decades at the University of Cambridge for electrical power production analysis [36-37]. The software models gas turbine performance as a non-idealized Brayton cycle using first and second law thermodynamic principles, where isentropic efficiencies of compression, expansion, heat transfer, etc. are included. A combustion subroutine allows for calculation of fuel heat release and turbine inlet temperature, and the turbine expansion subroutine allows for calculation of power production and exhaust gas temperature. A conservation of energy analysis within the HRSG subroutine calculates the heat transfer from the exhaust gas to the steam, thus determining how much thermal energy is available for refinery use. The parameters used in this study are summarised in Table 1. 
Table 1: CHP plant operating parameters

\begin{tabular}{|c|c|c|c|c|}
\hline & Value & $\begin{array}{l}\text { Range for } \\
\text { Sensitivity Analysis }\end{array}$ & Unit & Source \\
\hline LHV natural gas & 48 & - & $\mathrm{MJ} / \mathrm{kg}$ & [29] \\
\hline Air-fuel mass ratio & 34.6 & - & & Typical range \\
\hline Turbine efficiency & $27 \%$ & $25 \%-35 \%$ & & Typical range \\
\hline Turbine exhaust temperature & 841 & $500-850$ & Celsius & Typical range \\
\hline HRSG efficiency & $80 \%$ & $65 \%-85 \%$ & & Typical range \\
\hline HRSG exhaust temperature & 140 & $140-200$ & Celsius & Typical range \\
\hline Natural gas cost (LHV) & 4.22 & $3.00-8.00$ & $\$ / G J$ & [30] \\
\hline Electricity cost & 0.0706 & $0.05-0.10$ & $\$ / \mathrm{kWh}$ & [31] \\
\hline $\begin{array}{l}\text { Electricity GHG emissions } \\
\text { factor }\end{array}$ & 503 & $300-600$ & $\mathrm{~g} / \mathrm{kWh}$ & {$[32]$} \\
\hline
\end{tabular}

\subsubsection{Biomass-Fired Boiler/CHP Plant}

Many articles have considered the combustion or gasification of DDGS from practical and financial perspectives, e.g. [38-43]. There are many factors to consider, including the cost of alternative fuels, the price one can get from selling the DDGS, the price of equipment and the presence of some form of carbon tax/incentive. The current low natural gas price and the lack of a carbon incentive justifies that DDGS be sold as animal feed rather than burned as energy [43]. Therefore, this study only includes an analysis of natural gas-fired ethanol plants.

\section{RESULTS AND DISCUSSION}

\subsection{Base Case}

The modelled pure ethanol yield from corn was $0.43 \mathrm{~L} / \mathrm{kg}$, with a thermal energy use of 7.7 MJ/L, which are within 3\% of average reported values from those refineries surveyed and visited in 2014 (yield $0.42 \mathrm{~L} / \mathrm{kg}$ and energy use $7.5 \mathrm{MJ} / \mathrm{L}$ ). The ethanol yield is consistent with our previous studies, $0.41 \mathrm{~L} / \mathrm{kg}$, while energy use has decreased from the average of $10.2 \mathrm{MJ} / \mathrm{L}$ for data for 18 refineries between 1999 and 2009, but is still within the range of values found $(6.7-13.6 \mathrm{MJ} / \mathrm{L})[10]$.

\subsection{Natural Gas-Fired Corn-Ethanol Production}

The thermal energy requirement of each unit operation in the refinery was determined for various ethanol concentrations. Figure 4 (a) depicts the heat use by unit operation for anhydrous ethanol production. These results correspond well (within 10\%) to previous studies [11], while providing greater detail on distillation. Distillation is the largest energy use, accounting for $44 \%$ of total thermal energy use, but over two-thirds of this is used in the beer column to produce a distillate of around $58 \mathrm{wt} \%$ ethanol. Thus the energy savings to be derived from producing ethanol greater than $58 \mathrm{wt} \%$ is limited to that of the stripping column, accounting for $13 \%$ of overall energy use.

After distillation, drying is the next most energy intensive process. In all cases, drying consumed $35 \%$ to $40 \%$ of the total thermal energy of the refinery. Drying includes only the energy required for the rotary drum dryer, as the energy for evaporation is supplied from the heat of condensation from the rectifier condenser. The dryer receives the WDGS at approximately 65 wt $\%$ moisture and produces DDGS at $9 \mathrm{wt} \%$ moisture. The removal of this large fraction of 
water is energetically expensive, but prolongs the marketable life of distillers grains from less than a week to many months [44-45]. The energy used in the drying process leaves as low grade heat in the form of water vapor and is not recovered.

Locating corn ethanol facilities close to high density livestock operations would allow exporting of WDGS and thus reduce refinery energy use by up to 29\% and GHG emissions by up to $17 \%$, based on data obtained by Liske et al [46]. In practice, the reorganization of agricultural and livestock assets is challenging to achieve for the majority of refineries, due to constraints in land prices, suitability for production and existing infrastructure.

Figure 4 (b) illustrates that the energy saving achieved by producing $91 \mathrm{wt} \%$ ethanol is due to the decrease in energy required for the reboiler on the stripping column. It shows how the heat use for liquefaction offsets this gain between $58 \mathrm{wt} \%$ ethanol and $91 \mathrm{wt} \%$ ethanol. At $58 \mathrm{wt} \%$ ethanol, the stripping column and rectification column have been removed completely. The energy required for the beer column, dryers, and sterilization remains constant throughout all scenarios, while the energy required for dehydration is $1 \%$ of total energy use when producing anhydrous ethanol, which is eliminated for ethanol production below the azeotrope. 


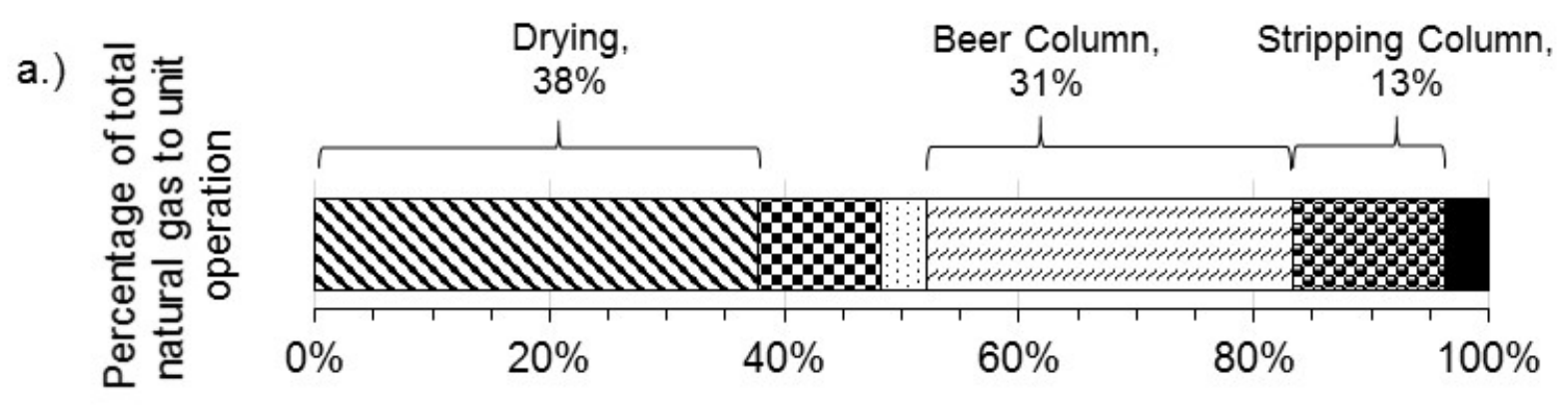

b.)
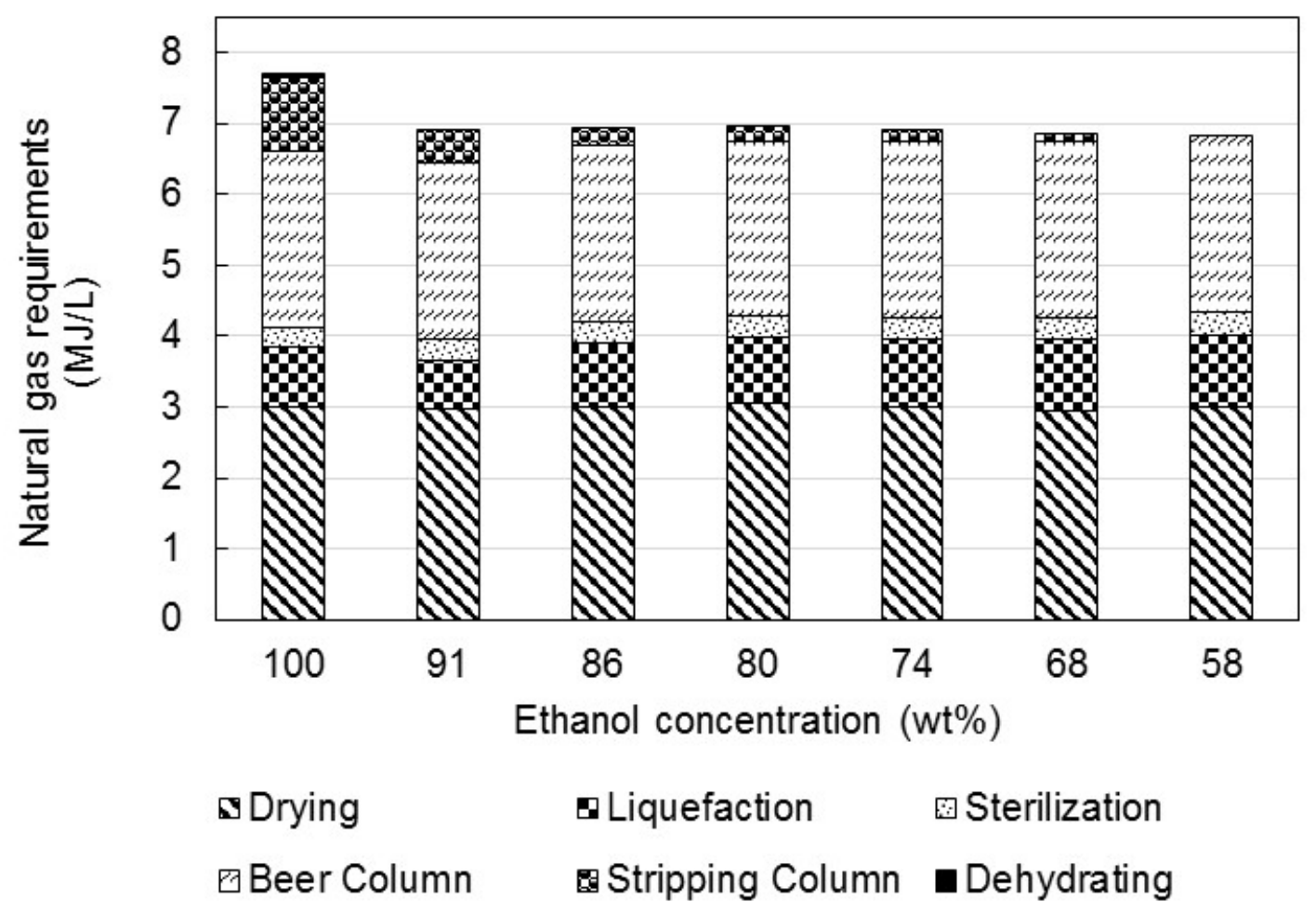

Figure 3. Refinery thermal energy use. (a) Breakdown of thermal energy use for each of the main unit operations for the anhydrous refinery. (b) Natural gas requirements for production of ethanol at various concentrations down to $58 \mathrm{wt} \%$ ethanol.

\subsubsection{Heat Integration}

The thermal energy (MJ of natural gas, LHV, per liter of ethanol produced) required to produce hydrous ethanol was determined for varying fractions of water content. The extent to which water can be removed from the solids (distillers grains) in the evaporators using process waste heat from elsewhere in the refinery impacts the additional thermal energy required within the dryer, where $35 \%$ solids leaving the evaporator is a typical refinery value, $45 \%$ is a best case scenario due to viscosity and scaling issues that start arising above $42 \%$, and $55 \%$ is a hypothetical best case scenario if these issues can be overcome. A "pinch" analysis corresponds to the theoretical minimum energy requirements for an optimally integrated refinery with $45 \%$ solids from the evaporators.

As shown in Figure 3, a 10\% energy use savings relative to anhydrous ethanol production was achieved by producing $91 \mathrm{wt} \%$ ethanol, which is a result of removing the molecular sieve. The 
primary energy savings occurs within the stripping and rectifying column due to the reduced mass flow in the column once the regeneration recycle stream is removed. Below $86 \mathrm{wt} \%$ ethanol, the energy savings diminish for increased water content, with a total of $1 \%$ reduction at $58 \mathrm{wt} \%$ relative to $86 \mathrm{wt} \%$. The mass flow through the final condenser increases due to the additional water in the product at lower ethanol concentrations which results in more heat availability than what can be absorbed in the evaporators. This additional heat availability at lower concentrations is not able to be returned to the process via the stripping column bottoms and is lost to the cooling towers. To compensate, additional steam is used in liquefaction, which offsets the savings achieved in the stripping column.

The difference between the pinch line and operating line indicates the potential that refineries have to save energy relying on temperature differences to drive heat transfer, e.g. without incorporating heat pumps. The energy savings associated by moving to the pinch line is $20 \%$ for anhydrous ethanol, $15 \%$ for $91 \mathrm{wt} \%$ ethanol and nearly $29 \%$ at $58 \mathrm{wt} \%$ ethanol. The degree to which a specific refinery will be able to utilize additional waste heat depends on the layout of the refinery, the capital cost of required equipment, and the exact ethanol concentration required. Figure 3 also shows the potential gains of increasing the solids concentration from the evaporators for reducing overall energy use, with refinery survey results indicating typical solids concentrations from the evaporators of 32-38\% (maximum reported $42 \%$ ). The evaporator slurry viscosity increases because of the presence of the yeast cell bodies, and scaling is the result of calcium in the water precipitating out as calcium oxalate, or "beerstone". The multi-effect evaporators have the capacity to further remove water, and sufficient excess heat is available, but the viscosity and scaling currently prevent solids concentration greater than $45 \%$.

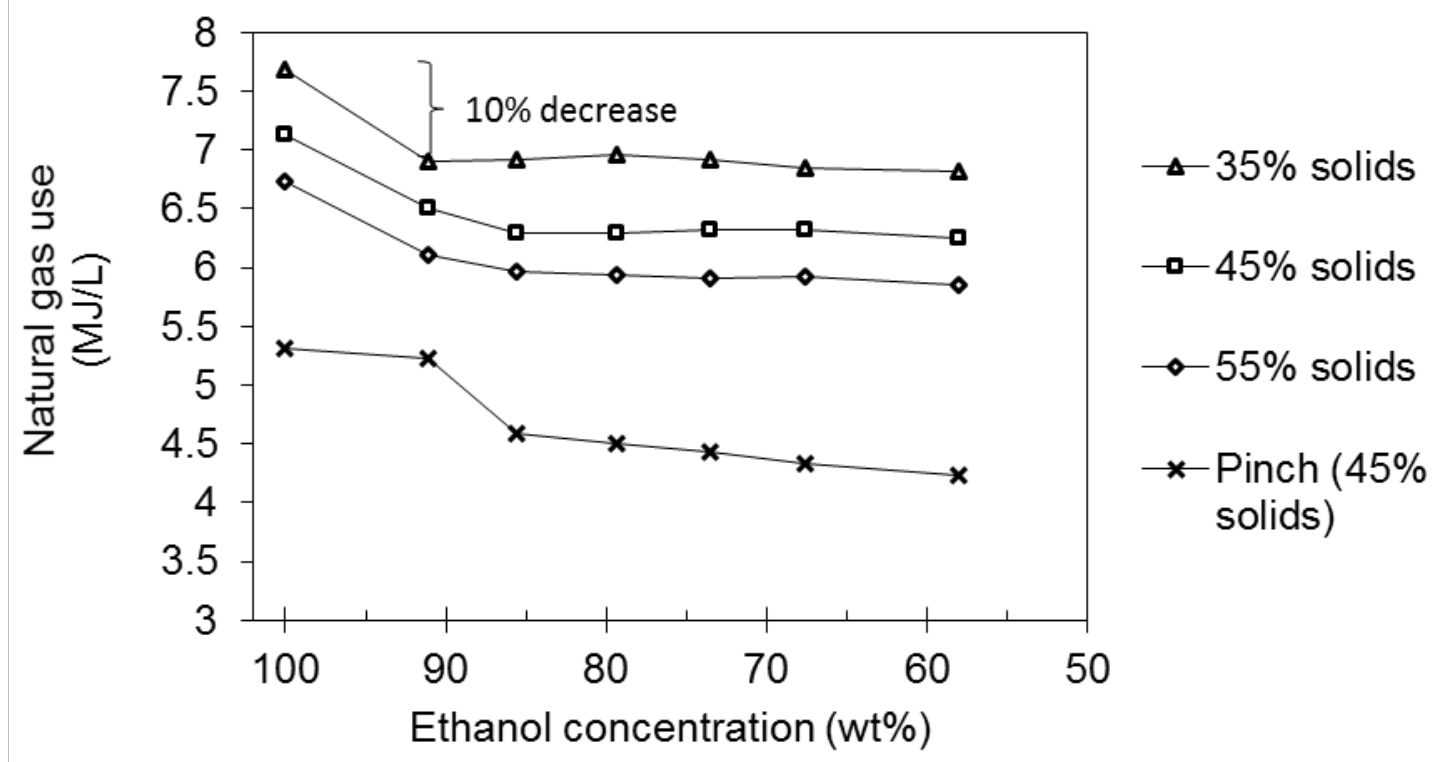

Figure 4. Natural gas use as a function of ethanol concentration for different evaporator performance (percent solids after evaporation), as well as the best case (pinch) heat use for a refinery with $45 \%$ solids from the evaporator.

\subsubsection{Total Carbon Dioxide Production}

The combined greenhouse gas (GHG) emissions for the different ethanol fractions are presented in Figure 6. Total refinery emissions for pure ethanol production of $544 \mathrm{~g} \mathrm{CO}_{2} \mathrm{e} / \mathrm{L}$ 
corresponds to $25.8 \mathrm{~g} \mathrm{CO}_{2} \mathrm{e} / \mathrm{MJ}$, roughly $40 \%$ of the total FCI of $64 \mathrm{~g} \mathrm{CO}_{2} \mathrm{e} / \mathrm{MJ}$ calculated by Boies et al. [10] when not accounting for land use change. Producing hydrous ethanol of 86 wt\% decreases refinery GHG emissions by $8 \%$, or $47 \mathrm{~g} \mathrm{CO}_{2} \mathrm{e} / \mathrm{L}$. For a $100 \mathrm{MGY}$ refinery, this corresponds to a decrease of nearly 2 tonnes of $\mathrm{CO}_{2} \mathrm{e} / \mathrm{h}$, or $16000 \mathrm{t} /$ year. Below $86 \mathrm{wt} \%$ ethanol, the additional savings become negligible.

Complete heat integration (i.e. operating at the pinch) would result in an additional $15-25 \%$ decrease in refinery GHG emissions, or 7.1 - $8.8 \mathrm{~g} \mathrm{CO}_{2} \mathrm{e} / \mathrm{MJ}$. The availability of further heat integration indicates that refiners can achieve further GHG reductions.

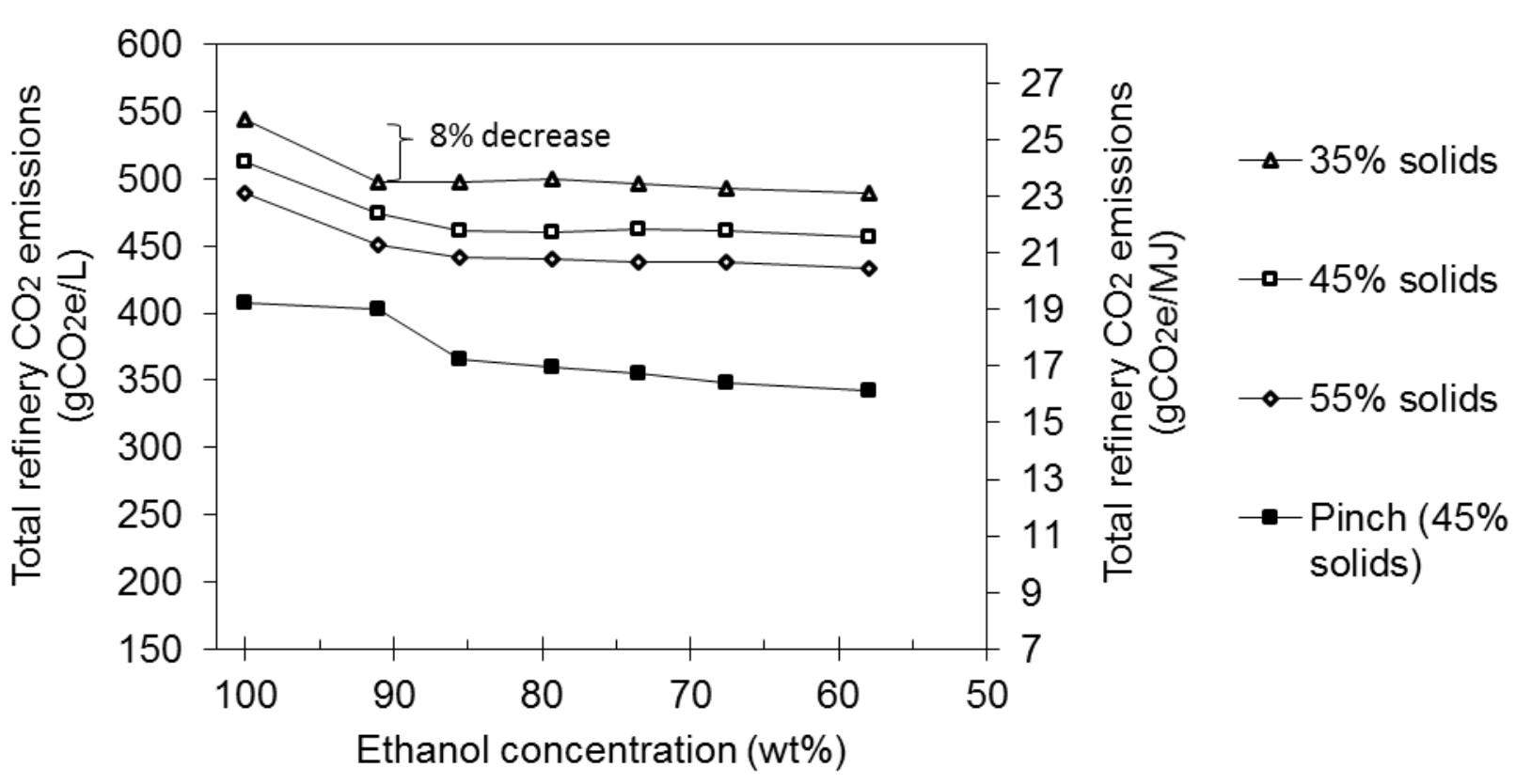

Figure 5. Total refinery greenhouse gas emissions as a function of ethanol concentration for different evaporator performances, as well as emissions associated with an optimal integrated refinery with $45 \%$ solids from the evaporators.

\subsubsection{Water Use}

The total water use is shown in Figure 7, where a minimum is evident at $86 \mathrm{wt} \%$ ethanol. As the water content of the ethanol increases, process water use increases accordingly (more water leaves as final product). However, due to the decreased heating requirements for hydrous ethanol production, there is less required cooling. This results in lower cooling water flow and therefore lower evaporative losses from the cooling towers. The decrease in evaporative losses is greater than the increase in water leaving as final product down to a concentration of $\sim 74 \mathrm{wt} \%$ ethanol. A decrease in water use of $3 \%$ and $6 \%$ is possible for evaporator solids concentrations of $35 \%$ and $45 \%$ solids, respectively. These results indicate that producing hydrous ethanol will save net water consumption in the refinery. 


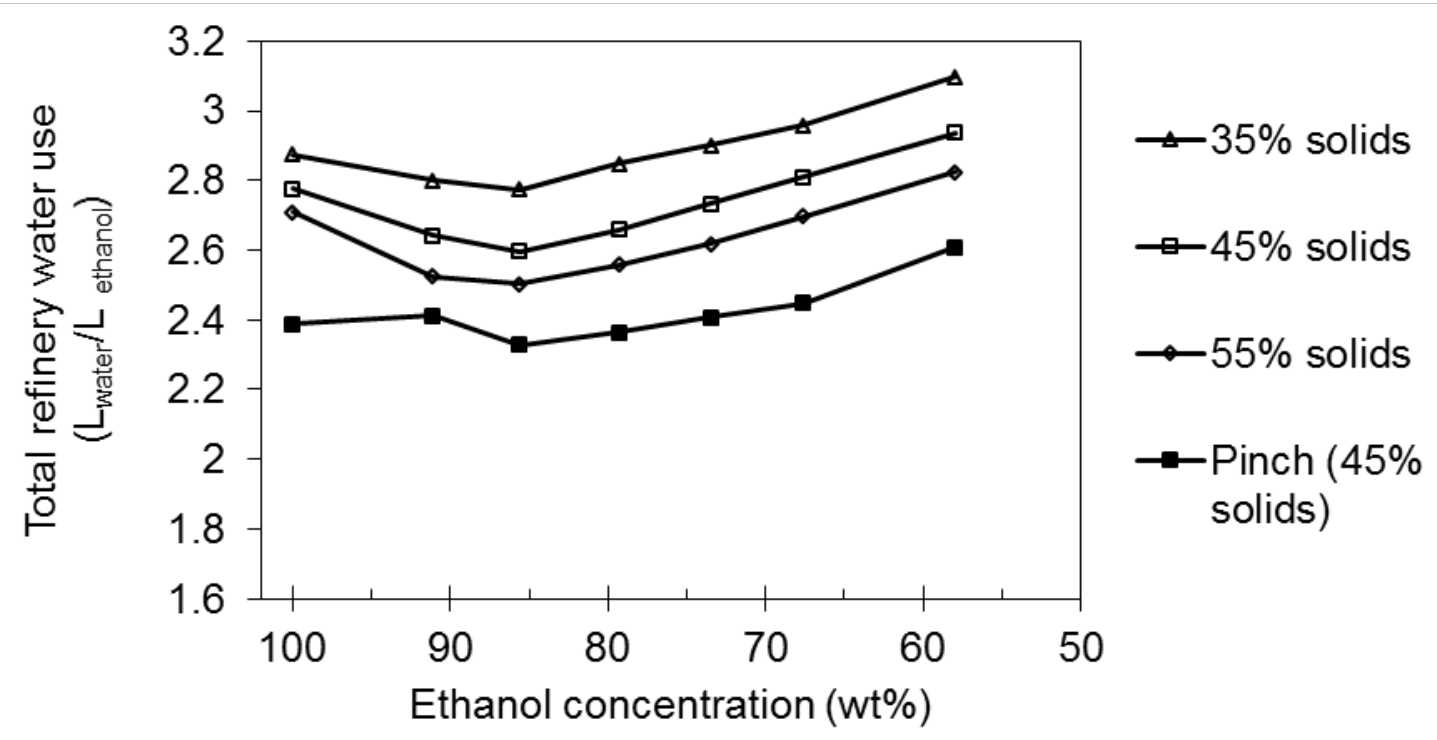

Figure 6. Total refinery water use as a function of ethanol concentration for different evaporator performance (percent solids after evaporation), as well as the best case (pinch) heat use for a refinery with $45 \%$ solids from the evaporator.

\subsubsection{Total Energy Costs}

The energy cost curves follow a similar trend to Figure 3 as the costs are directly affected by natural gas use. The decrease in energy costs by producing hydrous ethanol at $86 \mathrm{wt} \%$ amounts to a savings of approximately $8 \%(\$ 0.34 / \mathrm{L})$. For a $100 \mathrm{MGY}$ refinery, that corresponds to an energy cost saving of $\sim \$ 1.36$ million/annum. Below $86 \mathrm{wt} \%$ ethanol, the additional savings become negligible. Complete heat integration (i.e. operating at the pinch) would result in an additional $14-18 \%$ decrease in energy costs. This amounts to potential annual savings of over $\$ 2.6$ million/annum, which may justify the capital costs of heat integration for specific refinery layouts.

\subsection{Non-Hydrous Ethanol Refinery Options}

While hydrous ethanol production represents a potential reduction of $6-10 \%$ in energy, $\mathrm{CO}_{2}$ and water intensity, other options exist to improve corn ethanol production. Reductions from hydrous ethanol production are compared to other process improvements below.

\subsubsection{Exergy Analysis}

In order to identify the losses in the ethanol refinery, and thus, potential for refinery improvement, an exergy analysis was conducted for the refining system. Given a chemical exergy value for sucrose (5.896 $\mathrm{MJ} / \mathrm{gmol})$, the refinery exergy analysis was completed using sucrose as a proxy for the starch feed. A Sankey diagram depicting the calculated exergy flows is shown in Figure 5, where the width of the arrows is proportional to the magnitude of the exergy flow. The overall refining process of producing ethanol from corn starch is $70.1 \%$ efficient. Three processes account for nearly $86 \%$ of the total losses: the boilers, the dryers, and saccharification and fermentation. The rest of the unit operations on the refinery only account for $14 \%$ of the total losses. The distillation columns, the multi-effect evaporators, and liquefaction contribute $9 \%$ of the unit operations losses. Hydrous ethanol production predominantly affects the distillation, evaporation and liquefaction, and thus can at most recover only $9 \%$ of lost exergy. 


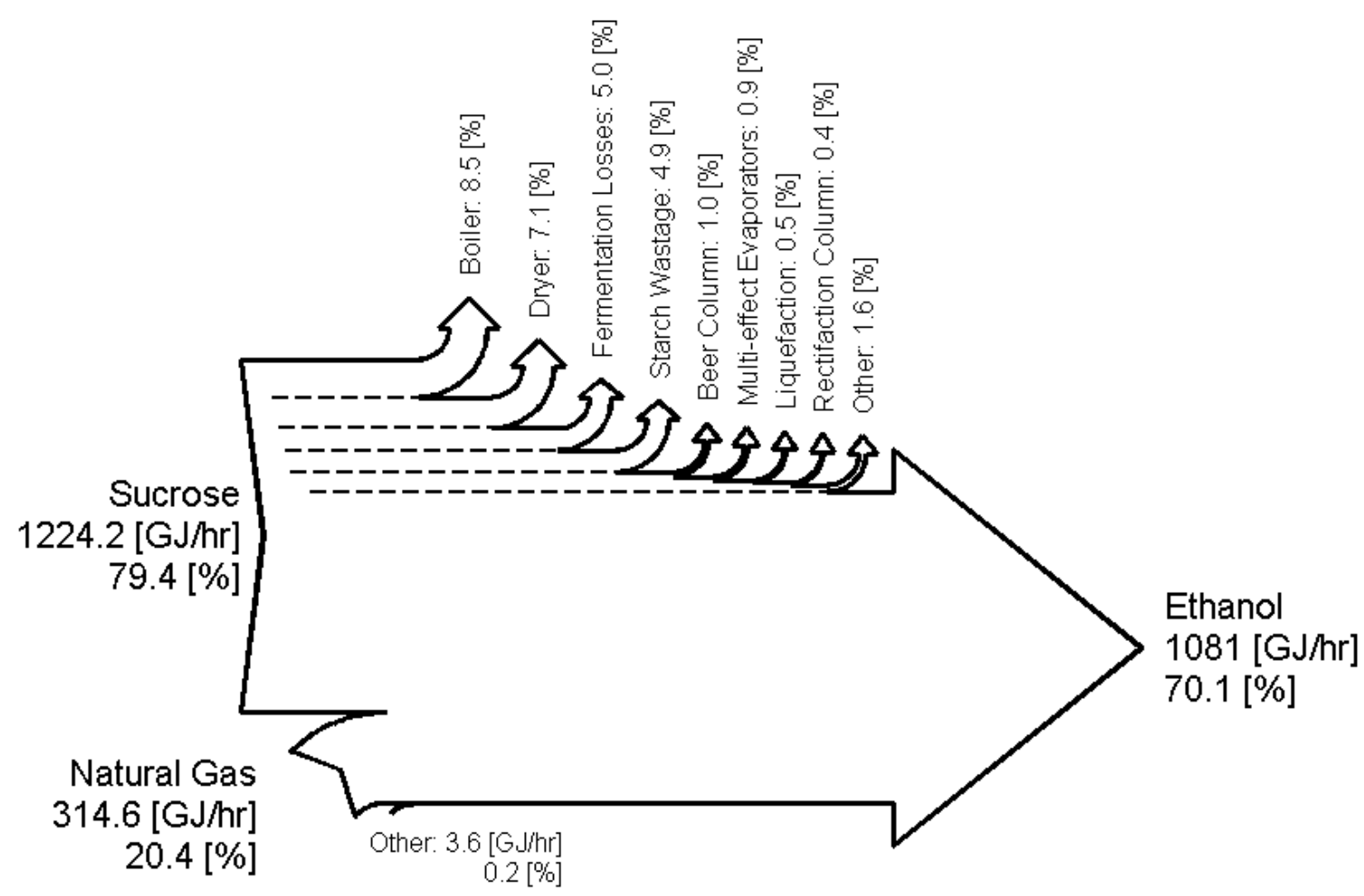

Figure 7. Sankey diagram for the exergy flows of the overall corn ethanol dry mill process.

\subsubsection{Fermentation Losses and Starch Wastage}

The combined losses from starch wastage and fermentation losses account for the largest portion of the exergy losses on a refinery. The ideal exergetic conversion of starch to ethanol (i.e. fermentation losses) is $\sim 92 \%$, but in reality only $86 \%$ of the exergy value of starch leaves the refinery in a useful form. This difference between the ideal conversion and actual conversion efficiency is defined here as "starch wastage", and occurs as a result of milling losses and incomplete conversion to ethanol. Milling losses are small $(\sim 0.3 \%)$ and are mostly due to particulate losses to the bag filters. Experimental and plant data have shown that there is a $99 \%$ conversion of the remaining starch to glucose, and a $100 \%$ conversion of the glucose [22]. However, the selectivity of glucose to ethanol is only 95\% (with the remainder being converted to by-products such as acetic acid) [22]. The resulting overall conversion of starch to ethanol is $\sim 94 \%$ (i.e. once the recycle in the plant has been accounted for). The seemingly small $6 \%$ loss is equivalent to $\sim 17 \%$ of the total refinery's thermal energy if completely converted to ethanol and could improve the net energy ratio of corn-ethanol by between $9 \%$ and $12 \%$ (depending on initial energy consumption), and reduce refinery GHG emissions by 14\%.

\subsubsection{Boiler and Dryer Losses}

Total exergy losses attributed to the boiler and dryer are $9 \%$ and $7 \%$, respectively. The combustion process in both these unit operations is inherently inefficient where methane and air are combusted at room temperature to produce products at the adiabatic flame temperature of $\sim 2500^{\circ} \mathrm{C}$, which destroys $\sim 30 \%$ of methane's exergy [35].

Although the thermal efficiency of the heat transfer is high in the case of the boiler (90\%) the ability to do work decreases according to Carnot's Law. The exergy efficiency of the total boiler system (i.e. methane and oxygen combusting to produce steam) was $\sim 28 \%$, thus $42 \%$ of the 
exergy is lost transferring the heat from the hot combustion gases to the saturated steam at $743^{\circ} \mathrm{C}$.

The lower thermal efficiency of the dryer (70\%) accounts for some of the dryer exergy losses, however, none of the low grade exhaust heat in the form of evaporated water from the dryer is recovered, and no energy can realistically be recovered from the warm DDGS. All of the exergy input to the dryer is lost. Therefore, combusting natural gas to evaporate water can be viewed as highly inefficient. One option to overcome this is to use a CHP plant to extract more work from the natural gas.

\subsubsection{CHP Plant}

The exergy analysis shows that additional work could be extracted from the natural gas by using a gas turbine CHP plant to produce electricity for the refining process in addition to thermal energy for drying the DDGS. The results for a refinery that incorporates a CHP are shown in Table 2, where the current base case is compared to plant configurations with a CHP that provides (Option 1) a large NG turbine capable of providing the thermal energy demand (steam requirements and DDGS drying) but exceeds refinery-required electricity demand, whereby excess electricity is sold back to the grid; (Option 2) a NG gas turbine that meets refinery steam use, but requires additional refinery natural gas to dry the DDGS, and sells excess electricity back to the grid; and (Option 3) a small GT to provide steam and electricity, and use the excess electricity to drive a heat pump. Option 1 has both the lowest GHG emissions (18\% below the base case) and the highest gross profit due to the amount of electricity sold back to the grid. In a Monte-Carlo simulation using uniform distribution of the variables in Table 1, Option 1 is profitable in $>90 \%$ of simulations, and outperforms Options 2 and 3 in all scenarios. Only when the electricity price is near its low limit $(\$ 0.05 / \mathrm{kWh})$ or the gas price is near its high limit (\$8/GJ) does Option 1 lose money.

Table 2: Comparison of CHP plant options

\begin{tabular}{llllll}
\hline & & Base case & Option 1 & Option 2 & Option 3 \\
\hline & $\begin{array}{l}\text { Natural gas } \\
\text { for thermal } \\
\text { energy \& buy } \\
\text { electricity }\end{array}$ & $\begin{array}{l}\text { Large GT \& } \\
\text { sell } \\
\text { electricity }\end{array}$ & $\begin{array}{l}\text { Small GT, } \\
\text { natural gas- } \\
\text { fired drying } \\
\text { \& sell } \\
\text { electricity }\end{array}$ & $\begin{array}{l}\text { Small GT \& } \\
\text { heat pump }\end{array}$ \\
\hline $\begin{array}{l}\text { Natural gas } \\
\text { required }\end{array}$ & $\begin{array}{l}\text { MJ/h } \\
(\mathrm{LHV})\end{array}$ & 337924 & 769253 & 453859 & 354821 \\
\hline $\begin{array}{l}\text { Net electricity } \\
\text { to export }\end{array}$ & $\mathrm{kWh}$ & -9538 & 48156 & 24501 & 0 \\
\hline $\begin{array}{l}\text { Gross profit } \\
\text { Net GHG }\end{array}$ & $\mathrm{kg} \mathrm{CO2e/h}$ & $-2,102.40$ & 146.81 & -775.37 & $-1,500.46$ \\
emissions & & 24059 & 19625 & 21443 & 20225 \\
\hline
\end{tabular}

\subsubsection{Discussion of Refinery Interventions}

The implications of this work in terms of energy, $\mathrm{CO}_{2}$, water and NER are summarized in Table 3. While all of the proposed interventions can be implemented together, the production of hydrous ethanol is the only intervention that simultaneously reduces energy, $\mathrm{CO}_{2}$ and water intensity. Heat integration allows for greater savings in energy and $\mathrm{CO}_{2}$, but may be limited by capital costs of integrating disparate processes within the refinery. Ultimately, heat integration 
will be undertaken when financially advantageous, and the long-term trend of refiners is to incorporate more such measures. Wet DGS production achieves the largest energy reduction, but necessitates confinement animal feeding to be located near ethanol production. Given current land use and value, it is unlikely that a shift in such practices will result in co-location of animal feeding near ethanol refining solely for the purposes of refinery energy savings. Natural gas CHP plants achieve significant CO2 reductions and likely achieve system-wide energy reductions depending on the manner in which the displaced electricity is produced. CHP requires upfront investment capital but is ultimately profitable in greater than $90 \%$ of electric and gas price scenarios. Better starch conversion decreases energy and $\mathrm{CO}_{2}$, but has been the primary focus of refiners for years. Thus starch conversion is unlikely to see significant gains due to yeast technology maturity over the last several decades of development. Similarly, improvements in the processing of DGS at higher solid fractions can achieve a 5-10\% reduction in energy use, $\mathrm{CO}_{2}$ emissions and water consumption (see Figures 4-6), but has received considerable development attention without significant gains.

Table 3: Implications for energy, $\mathrm{CO}_{2}$, water and net energy ratio

\begin{tabular}{|c|c|c|c|c|}
\hline \multirow[b]{2}{*}{ Intervention } & \multicolumn{3}{|c|}{ Maximum reduction } & \multirow{2}{*}{$\begin{array}{l}\text { \% increase in } \\
\text { lifecycle NER }\end{array}$} \\
\hline & Energy $^{1}$ & $\mathrm{CO}_{2}$ & Water & \\
\hline Hydrous ethanol (> 58 wt\% EtOH) & $10 \%$ & $8 \%$ & $3-6 \%$ & $5-7 \%$ \\
\hline Heat integration ${ }^{3}$ (> 58 wt\% EtOH) & $29 \%$ & $25 \%$ & - & $16-22 \%$ \\
\hline Wet DGS & $40 \%$ & $32 \%$ & - & $23-33 \%$ \\
\hline Natural gas CHP plant ${ }^{4}$ & $0 \%$ & $18 \%$ & - & $0 \%$ \\
\hline Better starch conversion & $17 \%$ & $14 \%$ & - & $9-12 \%$ \\
\hline \multicolumn{5}{|c|}{$\begin{array}{l}{ }^{1} \text { Maximum decrease to thermal energy use derived from natural gas } \\
2 \text { Based on an initial net energy ratio (NER) of } 1.3 \text { (lower bound) to } 1.7 \text { (upper bound) } \\
{ }^{3} \text { When operating at the pinch } \\
{ }^{4} \text { Excluding natural gas and emissions associated with electricity sales }\end{array}$} \\
\hline
\end{tabular}

\subsubsection{Applicability to Sugarcane Ethanol}

The above hydrous ethanol study focused on ethanol production from corn. Sugarcane refineries using distillation and molecular sieves to produce anhydrous ethanol will see a similar decrease in energy use for the water removal stage (beer column, stripping column, and molecular sieve) when producing hydrous ethanol. However, as sugarcane refineries have a different energy use profile (e.g. no energy is required to dry DGS), the percentage decrease in total energy consumption is not comparable. A similar argument holds for refinery emissions and water use.

\section{CONCLUSIONS}

Hydrous ethanol is an attractive diesel fuel alternative, motivating the study of energy, $\mathrm{CO}_{2}$ and water savings of corn ethanol production with various concentrations of water content. By incorporating design changes within an existing refinery model that allows for various levels of water content, our results demonstrated that at $86 \mathrm{wt} \%$ ethanol thermal energy consumption is 
optimized, decreasing by $\sim 10 \%$ (from $7.7 \mathrm{MJ} / \mathrm{L}$ to $6.9 \mathrm{MJ} / \mathrm{L}$ ). These savings have the potential to reduce energy costs by approximately 8\% (\$0.34/L) and reduce refinery emissions by 8\% $\left(2 \mathrm{~g} \mathrm{CO}_{2} \mathrm{e} / \mathrm{MJ}\right)$. Production of hydrous ethanol reduced refinery water use due to decreased evaporative losses in the cooling towers, leading to water savings of between 3 - $6 \%$ at 86 wt $\%$ ethanol. These savings are comparable to other refinery improvement strategies, but have the added benefit of coming at little cost to the refiners relative to other interventions.

\section{AUTHOR INFORMATION}

\subsection{Corresponding Author \\ ${ }^{*}$ Tel +44(0)1223 746 972; email: amb233@cam.ac.uk \\ 6 ACKNOWLEDGEMENTS}

This work was supported in part by the Minnesota Corn Growers Association under contract number 1051-14EU and St Edmund's College (Cambridge, United Kingdom). The authors would like to thank Jeffrey Hwang for his help in producing the process flow diagrams.

\section{ABBREVIATIONS}

CHP, combined heat and power; CIP, clean-in-place; $\mathrm{CO}_{2}$, carbon dioxide; DDGS, dried distiller's grains with solubles; GHG, greenhouse gas; GT, gas turbine; HRSG, heat recovery steam generator; LHV, lower heating value; MGY, million gallons per year; NER, net energy ratio; USDA, United States Department of Agriculture; ARS, Agricultural Research Service; WDGS, wet distiller's grains with solubles;

\section{REFERENCES}

[1] U.S. Congress, 110th, "Energy Independence and Security Act of 2007, Public Law No. 110-114, Section 201,” US Statutes at Large, vol. 121, p. 1522, 2007.

[2] A. E. Farell, R. J. Plevin, B. T. Turner, A. D. Jones, M. O'Hare and D. M. Kammen, "Ethanol Can Contribute to Energy and Environmental Goals," Science, vol. 311, pp. 506-508, 2006.

[3] ASTM D4806, "Standard Specification for Denatured Fuel Ethanol for Blending with Gasolines for Use as Automotive Spark-Ignition Engine Fuel,," ASTM International, West Conshohocken, PA, 2014.

[4] T. W. Patzek, "Thermodynamics of the Corn-Ethanol Biofuel Cycle," Crit. Reviews in Plant Sci., vol. 23, no. 6, pp. 519 -567, 2004.

[5] D. Pimental and T. W. Patzek, "Ethanol production using corn, switchgrass, and wood; biodiesel production using soybean and sunflower," Natural Resources Research, vol. 14, no. 1, pp. 65-76, 2005.

[6] M. Dias de Oliviera, B. Vaughan and E. J. Rykiel, "Ethanol as Fuel: Energy, Carbon Dioxide Balances, and Ecological Footprint,” BioScience, vol. 55, no. 7, pp. 593-602, 2005.

[7] H. Shapouri, J. A. Duffield and M. Wang, "The energy balance of corn revisited,” Trans. of the American Soc. of Agricultural Engineers, vol. 46, no. 4, pp. 959-968, 2003. 
M. S. Graboski, "Fossil energy use in the manufacture of corn ethanol,” National Corn Growers Association, Washington, DC, 2002.

[9] M. Q. Wang, "Development and Use of GREET 1.6 Fuel-Cycle Model for Transportation Fuels and Vehicle Technologies," Argonne National Laboratory, Argonne, IL, 2001.

[10] A. M. Boies, D. McFarlane, S. Taff, W. F. Watts and D. B. Kittelson, "Implications of local life-cycle analyses and low carbon fuel standard design on gasohol transportation fuels,” Energy Policy, vol. 39, pp. 7191-7201, 2011.

[11] Minnesota Technical Assistance Programme, "Ethanol Benchmarking and Best Practices,” MnTAP, Minneapolis, 2008.

[12] R. Ladisch and K. Dyck, "Dehydration of ethanol: new approach gives positive energy balance,” Science, vol. 205, no. 4409, pp. 898-900, 1979.

[13] J. Carey and W. Lewis, "Studies in Distillation: Liquid Vapour Equilibria of Ethyl Alcohol-Water Mixtures,” Ind. Eng. Chem., vol. 24, no. 8, pp. 882-883, 1932.

[14] J. Martinez-Frias, S. M. Aceves and D. L. Flowers, "Improving life-cycle energy efficiency by direct utilization of wet ethanol in HCCI engines," J. of Energy Resources Tech., vol. 129, pp. 332-337, 2007.

[15] S. Al-Aheh, F. Banat and N. Al-Lagtah, "Separation of ethanol-water mixtures using molecular sieves and biobased adsorbents," Chemical Eng. Research and Design, vol. 82, no. A7, pp. 855-864, 2004.

[16] Sigma-Aldrich, "Technical Information Bulletin Al-143: Mineral Adsorbents, Filter Agents and Drying Agents,” Sigma-Aldrich, 2014. [Online]. Available: http://www.sigmaaldrich.com/chemistry/chemical-synthesis/learning-

center/technical-bulletins/al-1430/molecular-sieves.html. [Accessed 21 August 2014].

[17] S. Saxena, D. Vuilleumier, D. Kozarac, M. Kriek, R. Dibble and S. Aceves, "Optimal operating conditions for wet ethanol in a HCCI engine using exhaust gas heat recovery,” Appl. Energy, vol. 116, pp. 269-267, 2014.

[18] R. C. Costa and S. R. José, "Hydrous ethanol vs. gasoline-ethanol blend: Engine performance and emissions," Fuel, vol. 89, pp. 287-293, 2010.

[19] W. Fang, D. B. Kittelson, W. F. Northrop and J. Fang, "An experimental investigation of reactivity-controlled compression ignition combustion in a singlecylinder diesel engine using hydrous ethanol," in Proceedings of the ASME 2013 Internal Combustion Engine Division Fall Technical Conference ICEF2013, Dearborn, 2013.

[20] U.S. Department of Agriculture, "Aspen Plus ${ }^{\circledR}$ Dry Grind Ethanol Process and Microsoft Excel @ Cost Model,” Eastern Regional Research Center, ARS, USDA., Wyndmoor, PA, 2007.

[21] J. Cheng, Biomass to Renewable Energy Processes, Boca Raton: CRC Press, 2009.

[22] J. Kwiatkowski, A. McAloon, F. Taylor and D. Johnston, "Modeling the process and costs of fuel ethanol production by the corn dry grind process," Industrial Crops and Products, vol. 23, pp. 288-296, 2006. 
[23] A. McAloon, F. Taylor, W. Yee, K. Ibsen and W. Wooley, "Determining the cost of producing ethanol from corn starch and lignocellulosic ethanol," National Renewable Energy Laboratory, Golden, CO, 2000.

[24] F. Taylor, M. Kurantz, N. Goldberg, A. McAloon and J. Craig, "Dry-Grind Process for Fuel Ethanol by Continuous Fermentation and Stripping," Biotech. Prog., vol. 16, no. 4, pp. 541-547, 2000.

[25] R. Bothast and M. Schlicher, "Biotechnological processes for conversion of corn into ethanol,” Appl Microbiol Biotechnol, vol. 67, pp. 19-25, 2005.

[26] H. Renon and J. M. Prausnitz, "Local compositions in thermodynamic excess functions for liquid mixtures,” AIChE J., vol. 14, no. 1, pp. 135-144, 1968.

Aspen Technology, Inc, "Aspen Physical Property System: Physical Property Methods,” Aspen Technology, Inc, Burlington, MA, 2010.

[28] U.S. Environmental Protection Agency, "Climate leaders greenhouse gas inventory protocol offset methadology for Industrial Boiler Efficiency," Centre for corporate climate leadership, 2008.

[29] R. H. Perry, D. W. Green and J. O. Maloney (Eds), Perry's Chemical Engineers' Handbook, Seventh Edition, New York: McGraw-Hill, 1997.

[30] U.S. Energy Information Administration, "Natural Gas Prices," EIA, 7 July 2014. [Online]. Available: http://www.eia.gov/dnav/ng/ng_pri_sum_dcu_smn_a.htm. [Accessed 11 August 2014].

[31] U.S. Energy Information Administration, "Electric Power Monthly with Data for December 2013,” U.S Department of Energy, Washington, DC, 2014.

[32] International Energy Agency, "CO2 Emissions from fuel combustion," OECD/IEA, Paris, 2013.

[33] B. Linhoff and E. Hindmarsh, "The pinch design method for heat exchanger networks,” Chemical Eng. Sci., vol. 38, no. 5, pp. 745 - 763, 1983.

[34] J. Szargut, D. R. Morris and F. R. Steward, Exergy analysis of thermal and metallurgical processes, New York: Hemisphere Publishing Corporation, 1988.

[35] M. J. Moran and H. N. Shapiro, Fundamentals of Engineering Thermodynamics, fifth edition, Chichester: John Wiley \& Sons Ltd, 2006.

[36] J. H. Horlock, Advanced Gas Turbine Cycles: A Brief Review of Power Generation, Elsevier, 2013.

[37] R. W. Haywood, Analysis of engineering cycles: power refrigeration and gas liquefaction plant, Newness, 2012.

[38] A. Tavasoli, M. G. Ahangari, C. Soni and A. K. Dalay, "Production of hydrogen and syngas via gasification of the corn and wheat dry distiller's grains (DDGS) in a fixed-bed micro reactor,” Fuel Process. Technology, vol. 90, no. 4, pp. 472-482, 2009.

[39] A. Kumar, Y. Demirel, D. D. Jones and M. A. Hanna, "Optimization and economic evaluation of industrial production and combined heat and power generation from gasification of corn stover and distiller's grains," Bioresource Technology, vol. 101, no. 10, pp. 3696-3701, 2010. 
[40] R. V. Morey, D. G. Tiffany and D. L. Hatfield, "Biomass for electricity and process heat at ethanol plants,” in ASAE Annu. Int. Meeting, Tampa, FL, 2005.

[41] N. Kaliyan, R. V. Morey and D. G. Tiffany, "Reducing life-cycle greenhouse gas emissions of corn ethanol by integrating biomass to produce heat and power at ethanol plants,” Biomass and Bioenergy, vol. 35, no. 3, pp. 1103-1113, 2011.

[42] R. Morey, D. Hatfield, R. Sears, D. Haak, D. Tiffany and N. Kaliyan, "Fuel properties of biomass feed streams at ethanol plants," Appl. Eng. in Agriculture, vol. 25, no. 1, pp. 57-64, 2009.

[43] D. G. Tiffany and R. V. K. M. J. Morey, "Economics of biomass gasification/combustion at fuel ethanol plants,” Appl. Eng. in Agriculture, vol. 25, no. 3, pp. 391-400, 2009.

[44] F. Dooley, L. Cox and M. Cox, "Distillers Grain Handbook: A Guide for Indiana Producers to Using DDGS for Animal Feed,” Department of Agricultural Economics, Purdue University, West Lafayette, IN, 2008.

[45] U.S. Grains Council, "DDGS Handbook: A guide to Disiller's Dried Grains with Solubles (DDGS),” U.S. Grains Council, Washington, DC, 2012.

[46] A. Liska, H. Yang, V. Bremer, T. Klopfenstein, D. Walters, G. Erickson and K. Cassman, "Improvements in Life Cycle Energy Efficiency and Greenhouse Gas Emissions of Corn-EthanolJ,” J. of Ind. Ecology, vol. 13, no. 1, pp. 58-74, 2009. 